\title{
A Closer Look at the Academic Support Seeking Behaviour of Male Undergraduate Students
}

\author{
Asheena Singh-Pillay ${ }^{*}$, Jayaluxmi Naidoo \\ School of Education, University of KwaZulu-Natal, South Africa
}

Received July 14, 2020; Revised September 2, 2020; Accepted September 17, 2020

\section{Cite This Paper in the following Citation Styles}

(a): [1] Asheena Singh-Pillay, Jayaluxmi Naidoo, "A Closer Look at the Academic Support Seeking Behaviour of Male Undergraduate Students," Universal Journal of Educational Research, Vol. 8, No. 11, pp. 5342 - 5350, 2020. DOI: 10.13189/ujer.2020.081136.

(b): Asheena Singh-Pillay, Jayaluxmi Naidoo (2020). A Closer Look at the Academic Support Seeking Behaviour of Male Undergraduate Students. Universal Journal of Educational Research, 8(11), 5342 - 5350. DOI: 10.13189/ujer.2020.081136.

Copyright $\subseteq 2020$ by authors, all rights reserved. Authors agree that this article remains permanently open access under the terms of the Creative Commons Attribution License 4.0 International License

\begin{abstract}
This qualitative case study embraced Social Construction theory to explore undergraduate male students' perceptions on the academic support provided at one university as well as their engagement in academic support seeking. The study aimed to examine the influence of masculinity on academic support seeking behaviour. Volunteer sampling was used to collect data from seventy undergraduate male students in the School of Accounting. An open-ended questionnaire and semi structured interviews were used to collate data. Data generated was subjected to content analysis which revealed that participants are aware of the academic support available to them and that they consider certain forms of non-academic support as necessary for their academic success. The findings revealed that participants engaged in academic support seeking via Academic Development Officers, specialist tutors, lecturers, peers, family members and no one. The findings exhibit the need for a greater understanding by lecturers and the relevant personnel of how masculinity impacts academic support seeking behaviour of undergraduate male students. The findings of this study reveal that for students to excel at university they need more than just academic support as their basic needs for food, financial support and health care must be met. Further findings illuminate that undergraduate male students' decisions and behaviours are profoundly shaped by rigid social and cultural expectations related to masculinity. The findings of this study are significant as they subvert the findings of previous studies that men avoid help seeking behaviour.
\end{abstract}

Keywords Academic Support Seeking Behaviour, Male Undergraduate Students, Masculinity, Socially Constructed Gender Norms

\section{Introduction}

Transition from a school to a university context is challenging for the students and may result in anxiety, poor academic performance, and increased dropout rates, Yorke and Longden, [1], Briggs, Clark \& Hall, [2]. Students with diverse cognitive abilities and backgrounds are entering Higher Education Intuitions (HEIs) hence additional academic support is being made available to assist these students and ensure they do not drop out, Lardner, [3]. This support includes strengthening study skills, academic writing skills, Irvin, [4] and subject specific support, van Veggel \& Amory, [5] to address gaps in subject knowledge and understanding. Student support programmes are designed to help students in improving their academic skills, Junio-Sabio, [6], decreasing attrition rates among students, increasing graduation rates and promoting graduate and professional programs, Ciobanu [7]. In spite of the academic support available to students, research demonstrates that most students do not seek formal help, Mau \& Lyn, [8]; Taylor \& Lorimer [9]; Sax, [10]; Penn-Edwards \& Donnison, [11] due to the misconception that asking for assistance is a sign of weakness. In particular, studies conducted by Randell, Jerdén, Öhman, 
Starrin and Flacking [12], Wimer and Levant, [13], Perkins [14] and Harris, [15] and Davis [16] have shown that male students are unlikely to engage in help-seeking behaviours for fear of being emasculated or perceived as incompetent. These scholars argue that socially constructed gender norms of what it means to be masculine dictate how men ought to behave, for instance these norms include that men do not display physical or emotional weakness; avoid acting in a feminine way; engage in risky behaviour (including participation in violence) and avoid seeking help. Further, the above-mentioned scholars assert that men are less inclined to engage in behaviours that are traditionally defined as feminine as they conflict with socially learnt lessons about masculinity.

In this paper, we argue that whilst male undergraduate students subscribe to socially constructed norms of masculinity, they simultaneously seek academic support. The objective of this study was to: explore the perceptions of undergraduate male students on support provided at Westwood University (pseudonym), establish the ways in which undergraduate students engage in academic support seeking behaviour and explore the influence of masculinity on academic support seeking behaviour. The research questions that undergirded this study are:

i What are the perceptions of undergraduate male students about academic support provided at Westwood University?

ii In what ways do undergraduate male students engage in academic support seeking behaviour?

iii What is the influence of masculinity on undergraduate male students' academic support seeking behaviours at Westwood University?

In this study, we hope to reform support strategies, dismantle barriers and assumptions about academic help seeking at Westwood University by gaining deeper insights into undergraduate male students' academic support seeking behaviour.

\section{Literature Review}

\section{Male enrolment at educational institutions}

In the 1980 s, $50 \%$ of the tertiary population comprised male students and 23 years later, in 2013, women accounted for $54.3 \%$ of all tertiary students globally, World Bank, [17]. This trend of diminishing enrolment of male students is also prevalent within the South African context, where women comprise $58 \%$ of total student enrolment and males $42 \%$, DHET, [18]. The diminishing enrolment of male students is attributed to male students struggling with socially constructed norms, what it means to be male and their lack of academic help seeking behaviour, Randell, Jerdén, Öhman, Starrin and Flacking [12], Wimer and Levant,[13], Perkins [14], Harris [15], Davis [16] and Edwards and Jones [19].

\section{Help seeking behaviours of men}

Studies by Addis and Mihalik [20]; Blazina and Watkins [21] as well as Rochlen and O’Brien [22] reveal that traditional gender stereotypes associated with male behaviour such as being in control and independent prevents men from seeking medical help, emotional help or academic support seeking help.

Academic support seeking behaviour entails seeking help to improve one's struggling class performance or understand difficult concepts, Koc and Liu [23]. According to Payakachat, Gubbins, Ragland, Norman, Flowers, Stowe, De Hart, Pace, \& Hastings, [24] students who need academic support , avoid seeking it because seeking help is linked to motivation, ego-achievement goals, classroom dynamics, feelings of inadequacy, stigmatization and characteristics of helpers. Similarly, Viandan [25] and Karabenick and Knapp [26] noted that male students who were struggling academically were less likely to seek academic support from academic staff due to social pressure to succeed independently as well as the belief that their peers did not need to seek academic assistance. These scholars further noted that avoidance of academic help seeking impacts retention rates, engagement and through put rates.

\section{Theoretical framework}

This study is undergirded by Social Construction theory. According to Paechter, [27]; Connell \& Messerschmidt, [28]; and West \& Zimmerman, [29], social construction theory is concerned with how meanings are attached to people and their behaviour by the societies in which we live. These scholars assert that society dictates how men and women should behave, achieve or perform gender. This means that gender is a social phenomenon, learnt from interactions with others and a reproduction of expected behaviour. With regard to the aforementioned point, it is worth noting that, Burke \& Stets, [30] posit that women are associated with femininity, which is characterized as being passive, cooperative, capable of asking for help, subordinate, not being in charge, emotional, and good at verbal skills, while masculinity according to Koenig, [31] is related to men being dominant, breadwinners, in control, competitive, autonomous, strong, not seeking help and good at Mathematics and Science. Performing or doing gender, according to West \& Zimmerman, [29] involves making use of discrete, well-defined behaviour that can be linked to interactional situations to produce recognizable enactment of masculinity and femininity.

During the analysis of data, key features of social construction theory, namely performance of gender will be used to illuminate when undergraduate male students "do gender" or "undo" gender and how they conform or avert masculinity norms, stereotypes, and ideologies related to undergraduate male students' academic help 
-seeking behaviour. Furthermore, the theory could be used to account for the ways in which undergraduate male students do or do not seek academic help as a product of masculine gender role socialization. It also provides a foundation for developing interventions that facilitate adaptive academic help seeking.

\section{Methodology}

This study adopted a qualitative approach to understand the social phenomenon explored from participants' perspectives, Cohen, Manion and Morrison, [32]. Permission to conduct this study was granted by Westwood University. A case study design was used to gain deeper insights into participants' perspective on their academic support seeking behaviour. An open ended questionnaire and semi structured interviews were used to gather data to ensure that thick descriptions of participants' lived experiences of, thoughts about, and feelings about academic help seeking behaviour were captured. The questionnaire comprised two sections. Section one focused on biographical data and section two focused on help-seeking behaviour, perceptions on support available, ways in which they sought academic support at Westwood university, how they become aware of the academic support available to them, their idea of what type of male behaviour is important to them and how being male impacts their academic support seeking behaviour. Undergraduate male students from the School of Accounting within the College of Law and Management Studies at Westwood University were invited to volunteer to participate in this study. Participants were assured of confidentiality and anonymity. Seventy undergraduate male accounting students responded to the invitation and completed the open-ended questionnaire. The invitation to be interviewed was included at the end of the survey questionnaire. The first 10 respondents ${ }^{1}$ formed the sample for the interviews. Each interview was of 30 minutes duration and was conducted at Westwood campus as per the negotiated times that suited the undergraduate male students. The interviews were audio recorded and transcribed verbatim.

Interview transcripts were sent to participants to allow them the opportunity to ensure that the data was captured correctly, and to avoid any misinterpretation by the researcher due to the possibility of mishearing what had been said during the audio recording of the interviews.

Content analysis was used to analyse the data. The data from the questionnaire and interviews were read and re-read to note patterns of similarities and dissimilarities before the data could be organised into categories. Each

${ }^{1}$ The following participants were interviewed: P3; P6; P10; P11; P18; P20; P29; P35; P40 and P55 author was assigned data to code more closely. The authors met several times to discuss their coding process and decision-making.

The letter $\mathrm{P}$ and a number were allocated to each participant ${ }^{2}$.

\section{Findings and Discussion}

This section focuses on three aspects, namely,

i Undergraduate male students' perceptions on academic support provided at Westwood University,

ii Ways undergraduate male students engage in academic help seeking and

iii The influence of masculinity on undergraduate male students' academic support seeking behaviours at Westwood University.

\section{Perceptions on academic support provided at Westwood University}

All seventy participants (100\%) indicated they were aware of the academic support provided at Westwood University as these were well advertised, there are adverts around the campus in the lecture rooms and notice boards (P6). Twenty-five students (36\%) were uncertain about the quality of the support provided, and 30 students (43\%) regarded the support provided as satisfactory and $15(21 \%)$ stated the support provided was good. Data from the questionnaire revealed that undergraduate male students within the School of Accounting identified 10 types of support provided at Westwood University. Table 1 reflects the type of support accessed by undergraduate male students as well as the number and percentage of students who accessed that type of support.

Table 1. Types of support accessed by students in the College of Law and Management Studies

\begin{tabular}{|c|c|c|}
\hline Support provided & $\begin{array}{c}\text { Number of } \\
\text { students seeking } \\
\text { support (N=70) }\end{array}$ & $\begin{array}{c}\text { \% of } \\
\text { students } \\
\text { N=70 }\end{array}$ \\
\hline $\begin{array}{c}\text { Academic Development } \\
\text { Officers (ADOs) }\end{array}$ & 65 & 93 \\
\hline Specialist tutors & 35 & 50 \\
\hline Writing place & 18 & 26 \\
\hline Library support -endnote & 45 & 64 \\
\hline Counsellors & 10 & 14 \\
\hline Financial support & 57 & 81 \\
\hline Disability unit & 5 & 7 \\
\hline Potential high-flyer support & 43 & 61 \\
\hline Clinic & 15 & 21.4 \\
\hline Food support & 15 & 21.4 \\
\hline
\end{tabular}

${ }^{2}$ Participant 10 was coded as P10, Participant 53 was coded as P 53 and so on. 
From Table 1, it is visible that forty-five students (64\%) found the support provided by the library services to be extremely beneficial as they learnt how to reference according to APA $6^{\text {th }}$ style and are aware of the plagiarism policy and software that detects plagiarism. Forty-three (61\%) students who valued academic excellence appreciated the potential high-flyer support programme, which provided mentorship and links to Alumni.

It is worth noting that male undergraduate students considered certain non-academic forms of support (financial, food, clinic and disability) which are essential for their well-being as a part of the academic support they require. Participant 55 captured the need for non-academic support as being a vital part of academic support:

many of us come from an impoverished background, we are the first generation to access university, our parents are poor, we are far from home we need money, food and medical care to succeed.

This finding elucidates that for students to excel and thrive at university their basic needs must be met. The one size fits all academic support provided by Westwood University does not necessarily consider its students' diversity and its needs.

\section{Ways undergraduate male students engage in academic help seeking}

Undergraduate male students engage in academic support seeking via ADOs, specialist tutors, lecturers/professors, peers, family members and no one. The six ways in which male undergraduate students seek support, reveal the various means in which they conform to normative masculinity and do gender as well as instances when they undo gender.

\section{- ADOs}

Sixty-five students (93\%) obtained help from the ADOs. Participant 6 captured why most students engage with ADOs when they need support:

ADO's are easily approachable, they are young, you can talk to them freely, ask them a question on something that you do not understand without feeling humiliated, rejected or being laughed at.

The emotional conundrum male students encounter when they seek academic support comes to the fore in the excerpt above. Their justification for approaching ADOs include being able to ask questions, without humiliation, rejection or being laughed at. It is evident that male students are unable and uncomfortable dealing with being vulnerable, degraded, devalued, laughed at or rejected when attempting to seek academic support. Fear of their emotions often prevents men from seeking help. Denial of emotions is a commonly reported contributor to non-help seeking among men, Hernan, Philpot, Edmonds, \& Reddy, [33]; Vogel, Wade, Wester, Larson, \& Hackler, [34].
Problems with interpreting, managing, and communicating distress can result in young men becoming caught in a cycle of avoidance of help seeking as reported by Biddle Gunnell, Sharp and Donovan [35] and Clement, Schauman, Graham, Maggioni, Evans-Lacko, Bezborodovs and Thornicroft [36]. The socially constructed norm for emotional inexpressiveness is important to men, it shows they are in control and thereby preserves their power in interpersonal contexts.

The expression of the above emotions is antithetical to ideas associated with normative masculinity. By expressing feeling of vulnerability and seeking academic support male undergraduate students, "undo" gender. Deviating from the norms associated with masculinity often results in censure from peers, social exclusion, and sometimes even emotional abuse, Clement et al., [36]. The confounding question is how do academic and support staff enable male students to express their fears about seeking academic support without feeling rejected and humiliated?

\section{- $\quad$ Specialist tutors}

Thirty-five students (50\%) preferred to get academic support from specialist tutors as these tutors provided discipline specific knowledge, can deconstruct the content into a simpler form, and were available after lectures. Participant 10:

indicated they are qualified, they know the content and the sections we struggle with, they will not expose or humiliate you and they are always available after the lecture for consultation.

Once again, the fear of seeking support and negative emotions associated with seeking support becomes visible. In a subdued way the control male students exercise over their learning, via the traits they value in the person they engage with, while seeking academic support highlights their socially constructed ideologies about what it means to be male, that is to be in control and not be humiliated. Even though undergraduate male students seek academic support they still "do gender" by conforming to normative masculinity of being in control and avoiding having to deal with emotions.

\section{- Lecturer/professor}

Five students indicated that they turned to the lecturer/professor for academic support. Participant 20 elaborated:

I make a point of going to the lecturer or professor, not for academic help just so he recognizes me and keeps me in mind for being a tutor when I complete.

From the excerpt, it is conspicuous that students use the resources (lecturer/professor) for reasons other than their intended purpose of providing academic support. From the excerpt male students' patterns of interaction and their perceived products of such interactions, which is employed 
as a tutor becomes evident. This means that these male students actively seek the support of persons in positions of power with an ulterior motive in mind. The importance of employment to men's success, the need to avert financial insecurity and the need to associate with persons in positions of power are linked to normative masculinity and men doing gender, Hoy, [37].

\section{- $\quad$ Peers}

Networking with peers proved to be a strong source of support. Nearly all participants $(n=68)$ indicated that they were most comfortable seeking support from their peers as compared to lecturers/ professors or other formal support at Westwood University. Additionally, peers in successive years of study advised participants on how to maximize their success, which sections to concentrate on and how to secure vacation work experience with the Big 4 Accounting companies. Participant 35 elaborated:

I work part-time to fund my study and often skip lectures; I have no funding from Funza or Nsfas. I am totally dependent on my peers for academic support. They explain better than the lecturers and focus on what I need to pass the exam.

The support from peers serves as a "brother hood" where male students are comfortable to be emotionally open and receive the social and academic support they require. This finding highlights the integral role that peers play in the provision of academic support to male students who need academic support. It alerts Westwood University's academic monitoring support unit to discern what mechanisms can be put in place to embrace peer support as part of the formal support available to male students.

\section{- $\quad$ Family members}

Participants also expressed that they leaned toward family support during times of difficulty. Of the 10 participants interviewed, seven (70\%) expressed that they reached out to family members, specifically their parents, when having a difficult experience. Participants had two main reasons for why they chose to use family members as a resource. Firstly, participants expressed admiration for their parents, and secondly, participants trusted and felt safe with their parents. This theme was especially salient when participants talked about their fathers. Participant 3 named his father as a role model as he was a successful charted accountant. Again, our data reveals that trust, emotional safety and secrecy are important to male students when they seek academic support. The big question is how universities ensure confidentiality and a safe space for male students to access the available academic support.

\section{- $\quad$ No one}

It was noted that five participants (7\%) valued their independence. When asked during the interview who they rely on when they are overwhelmed by the academic content/work participant 18 replied:

No one, I don't like asking for help, it make you look weak as a man, I study until I figure it out, and I do figure it out.

It is visible from the above excerpt that seeking help is a sign of mental and emotional weakness. It can be gathered that seeking help seemed to undermine the student's sense of independence and conflicted with his social construction of what it means to be a man. This above finding highlights the individual's degree of endorsement and internalization of socio-cultural norms and values regarding normative masculinity and the male gender role.

In a subtle way, the above 6 ways in which male students access support highlight the emotional challenge that male students encounter when they do and undo gender whilst they seek academic support.

\section{Influence of masculinity on undergraduate male students' academic support seeking behaviours}

Undergraduate male accounting students carry certain characteristics (physiological, cognitive, psychological, life experience, prior knowledge, etc.) and socially constructed norms of masculinity with them as they enter an educational programme. These socially constructed norms of masculinity enable them to do gender or undo gender. These characteristics and norms contribute to their academic profile and impact their academic help seeking behaviour. Data from the questionnaire and interview was used to establish the influence of masculinity on their academic help seeking behaviour.

\section{Masculine capital}

Studies by Doublin [38] and Levy Richardson, Lounsbury, Stewart, Gibson and Drost [39] reveal that people who were attracted to the field of accounting have a high level of conscientiousness. The undergraduate male accounting students exhibit the following forms of masculine capital namely: being a breadwinner, displaying a winning streak, control and physical strength. Put simply it means that undergraduate male accounting students do gender when they exhibit the various forms of masculine capital, Hadebe, [40].

\section{- Breadwinner}

Sixty-two participants (86\%) believe that making money, and being a breadwinner is their idea of being a successful man. These sentiments are reflected in the transcript excerpts:

men are breadwinners they must take care of their family, therefore I have to get help from ADOs and whoever it takes to succeed (P 11) and making money is important, accountants make lots of money (P 29). 
These students hold traditional views of men as primary earners, breadwinners and top income earners. Further, they see themselves in a position of power or control whereby they can provide essential resources for the survival of their family. In other words, they conform to normative masculinity of being in charge, in a position of power or control, hence they seek help from whoever to succeed. In embracing this notion of being breadwinners undergraduate male students adopt the stance of hegemonic masculinity. Hegemonic masculinity is the dominant form of masculinity in society, it is used to describe 'the ideal man' a man who provides for his family, Hadebe, [40]. The idea of being a breadwinner, being able to take charge and making money elucidates these male students' motivation and determination to be successful (breadwinners), Zimmerman \& Schunk, [41] hence they seek help from ADOs and whoever is available in order to gain status and power in the public sphere, Thébaud, [42]. The acquiring of high status and power is associated with success. Our finding resonates with Doublin's [38] study which illuminates that many students choose to study accounting as a major because of the perceived financial opportunities. When male students exhibit the desire to be breadwinners they conform to socio-cultural stereotypes of what it means to be a man and, in the process, they do gender.

\section{- $\quad$ Winning streak}

Thirty- eight participants (54\%) are of the view that competing with others is the best way to succeed, while 32 (46\%) students consider winning to be a measure of their value and personal worth. The excerpt from the interview highlights why winning is valued by this category of students:

winning is import to succeed...I have to be better than the other students so I seek help from lecturers without letting my friends know (P 55) dong well is important to remain at the top... successful men are winners (P 11) I evaluate people by their level of success... (P 3).

Our data reveals that for these students being competitive and winning are important indicators of their confidence, values, success, personal worth and their masculinity. Winning is associated with hegemonic masculinity, Hadebe, [40] which includes notions of confidence, respect and power that have contributed to our male students seeking the academic support provided at Westwood university. The need to be the best motivates these students, reinforces their competitive edge, and further strengthens their motivation to monitor their progress against that of other students. The need to outperform their peers academically forces male undergraduate students to seek help in a clandestine way to conform to normative masculinity and to do gender by not seeking help publicly. Our finding corresponds with that of DiMenichi and Tricomi's [43] study, which reveals that the pressure to win and succeed comes from sociocultural factors as well as intrinsic factors, Cretsinger, [44]. An important implication of this finding is for universities to (re)imagine how they can harness male students' normative masculinity to encourage them to seek academic support.

\section{- Control}

In this study, undergraduate male accounting students oversaw their studies and those around them. Thirty- eight students indicated that they needed to oversee themselves and those around them. The notion of being in control, was explicitly expressed by participants during the interview:

doing well all the time is important to me, its shows I'm in control, it also means I can be a leader, to stay on top of things you have to get help when you need it from ADOs, lecturers, profs, family (P 3), I feel I need to be in charge always (P40).

The need to be in control is associated with leadership aspirations and power, which are typical masculine traits, Hadebe, [64] and influence participants' academic help seeking behaviour positively. They actively seek help from ADOs, lecturers, professors and family. This finding illuminates the key traits (masculine capital) that universities need to tap into in their efforts to promote academic support seeking behaviour among male students.

\section{- $\quad$ Physical prowess}

The need to be physically stronger than other men is valued by 43 (61\%) of our participants. Furthermore, 32 (46\%) of these students preferred to feel superior to others. These sentiments were expressed during the interviews by participants:

having a six pack is important for a man - it shows your strength, you have be look good and excel academically, get help if you are not excelling (P10) ...if you are small built and not strong you are not taken seriously, they regard you as a loser, you must look the part of success (P 35).

The concept of having a fit and muscular body was a clear indicator that a manly appearance is valued among the participants as it was associated with the notions of strength and power. Consequently, the notions of strength and power are associated with success which influences undergraduate male accounting students to use academic and non-academic support provided at Westwood University. Our findings confirm that men do conform to sociocultural pressure to be physically big, have strength, and the ability to use their physique if necessary, to gain power.

\section{- Self-accountability}

The need to be responsible, work well within the university environment and be accountable for their academic progress was favoured by all 70 (100\%) participants. The notion of being accountable to the self, 
came to the fore in the interviews:

You are away from home, you are the first one in your family to come to university, you have to be responsible for your actions and progress (P55), I think of my academic achievement in terms of money, if I fail a year it means I will be one year behind my classmates in terms of earning, that is a lot of money to loose, so I have to make use of all the support provided to ensure I pass and pass well (P11).

The students in this study took ownership of their academic achievements by working with the all the academic support available to them at Westwood university. Our finding resonates with that of, Mapuya, [45] who asserts that when students are cognizant of their ability to thrive within their learning environment and are actively involved and responsible for their learning, they are bound to be successful academically. The challenge for universities is to encourage male students to be responsible and accountable for their academic success and support seeking behaviour.

\section{Conclusions}

Our findings confirm that all 70 participants were aware of the academic support provided at Westwood University via: ADOs, specialist tutors, writing place, library service, counselors, financial, disability unit, potential high- flyers, clinic and food. Undergraduate male accounting students engage in academic help seeking in six ways via ADOs, specialist tutors, lecturers/professors, peers, family members and no one. Our findings show that masculinity enables undergraduate male accounting students undo gender when they seek academic support whilst doing gender, that is, conform to social constructions of masculinity such as being a bread winner, embracing a winning streak, acting independently and in control and valuing physical prowess. The findings from this study illuminate that undergraduate male students' decisions and behaviours are profoundly shaped by rigid social and cultural expectations related to masculinity and are significant as they subvert the findings of studies by Addis and Mahalik [20] as well as Marrs, Sigler and Brammer [46] that men avoid help seeking behaviour.

\section{Limitations}

The study was not without limitations. The accelerated timeline and circumstances limited the research team's ability to interview a larger group of students. This small sample size prevented the researchers from gaining insight into the full breadth of experiences among undergraduate male accounting students. A further limitation was the absence of a quantitative component to the research approach used which would have allowed the research team the opportunity to establish correlations between variables. Additionally, the findings from this study make recommendations for further research into the associations between the 5 forms of masculine capital and from whom they seek help.

\section{Implications}

Broadening the discussion about how gender norms affect male students' support seeking behaviour helps us to better understand the complex ways that rigid gender norms and power relations burden our society, how to effectively engage male students in reflections about inequalities and change the university's academic support structures. Understanding undergraduate male students' support seeking behaviour, including how they have changed and their areas of resistance, is essential to moving these efforts forward and providing the required support.

If lecturers and role players within academic monitoring systems across campuses are aware of the ways masculinity influences male undergraduate students interact with their peers, it will allow these individuals to better serve the students. Additionally, understanding the process of academic help-seeking that occurs within the School of Accounting will inform higher education practitioners' approach to working with this population.

There is also a need for more research on the ways in which male undergraduate students are already moving toward "undoing gender", in order to identify ways to support and accelerate the change that is already happening at the School of Accounting at Westwood University.

\section{REFERENCES}

[1] Yorke M., Longden B., editors. (eds.). (2004). Retention and Student Success in Higher Education.Buckingham: Society for Research into Higher Education and Open University Press.

[2] Briggs A. R. J., Clark J., Hall I. (2012). Building bridges: understanding student transition to university. Qual. High. Educ. 18, 3-21. 10.1080/13538322.2011.614468

[3] Lardner, E. D. (2003). Approaching diversity through learning communities. Washington Center Occasional Paper, 2(1), 1-12.

[4] Irvin, L. L. (2010). What is "academic" writing? In C. Lowe \& P. Zemliansky (Eds.), Writing Spaces: Readings on Writing (Vol. 1, pp. 3-17). West Lafayette, IN: Parlor Press LLC.

[5] Van Veggel, N., \& Amory, J. (2014). The impact of maths support tutorials on mathematics confidence and academic performance in a cohort of HE Animal Science students. 
PeerJ, 1-11. Retrieved from doi:10.7717/peerj.463.

[6] Junio-Sabio, C. (2012). Importance of academic support services: An assessment by the students in Oman. International Journal of Information Technology and Business Management, 3(1), 14-22.

[7] Ciobanu, A. (2013). The Role of Student Services in the Improving of Student Experience in Higher Education. Procedia - Social and Behavioral Sciences, 92, 169 - 173.

[8] Mau, W. and Lynn, R. (2001). Gender differences on scholastic aptitude test, the American college test and college grades. Educational Psychology, 21(2), 133-136.

[9] Taylor, D., \& Lorimer, M. (2002). Helping boys succeed. Educational Leadership, 60(4), 1-4.

[10] Sax, L. (2008). The gender gap in college: Maximizing developmental potential of women and men. San Francisco, CA: Jossey Bass.

[11] Penn-Edwards, S., \& Donnison, S. (2011). Engaging with higher education academic support: A first year student teacher transition model. European Journal of Education, 46(4), 566-580.

[12] Randell, E., Jerdén, J., Öhman, A., Starrin, B., \& Flacking, R. (2016) Tough, sensitive and sincere: how adolescent boys manage masculinities and emotions, International Journal of Adolescence and Youth, 21:4, 486-498, DOI: 10.1080/02673843.2015.1106414

[13] Wimer, D.J. \& Levant, R.F. (2011). The relation of masculinity and help-seeking style with the academic help-seeking behavior of college men. The Journal of Men's Studies, 19(3), 256-274.

[14] Perkins T. (2015). On Becoming a Public Sociologist: Amplifying Women's Voices in the Quest for Environmental Justice. In: White S.K., White J.M., Korgen K.O., editors. Sociologists in Action on Inequalities: Race, Class and Gender. SAGE Publications; Los Angeles, CA, USA: 2015. pp. 88-92.

[15] Harris, F. (2010). College men's meanings of masculinities and contextual influences: Toward a conceptual model. Journal of College Student Development, 51(3), 297-318.

[16] Davis, T. L. (2002). Voice of gender role conflict: The social construction of college men's identity. Journal of College Student Development, 43 (4), 508-521.

[17] The World Bank, (2013). Higher education and development. An evaluation of world bank group support. Washington, DC: World Bank Group.

[18] Department of Higher Education and Training (2018). Statistics on Post-school education and training in South Africa, 2016, Department of Higher Education and Training, Pretoria, South Africa.

[19] Edwards, K. E. \& Jones, S. R. (2009). "Putting my man face on": A grounded theory of college men's gender identity development. Journal of College Student Development,50, (2), 210-228.

[20] Addis, M., \& Mahalik, J. (2003). Men, masculinity, and the contexts of help seeking. American Psychologist, 58(1), 5-14.

[21] Blazina, C., \& Watkins, C.E. Jr. (1996). Masculine gender role conflict: Effects on college men'spsychological well-being, chemical substance usage, and attitudes toward help seeking. Journal of Counseling Psychology, 43, 461-465.

[22] Rochlen, A.B., \& O’Brien, K.M. (2002). Men’s reasons for and against seeking help for career-related concerns. The Journal of Men's Studies, 11, 55-63.

[23] Koc, S.,\& Lia, X.(2016). An investigation of graduate students' help-seeking experiences, preferences and attitudes in online learning. The Turkish Online Journal of Educational Technology, 15( 3), 27-38.

[24] Payakachat, N., Gubbins, P.O., Ragland, D., Norman, S.E., Flowers, S.K., Stowe, C.D., De Hart, R.M., Pace, A., \& Hastings, J.K. (2013). Academic help-seeking behavior among student pharmacists. American Journal of Pharmacy Education. 77(1), 1-11.

[25] Vianden, J. (2009). Exploring college men's perceptions about interacting with faculty beyond the classroom. College Student Affairs Journal, 27(2), 224-241.

[26] Karabenick, S. A., \& Knapp, J. R. (1988). Help seeking and the need for academic assistance. Journal of Educational Psychology, 80(3), 406-408.doi:10.1037/0022-0663.80.3.4 06

[27] Paechter, C. (2003), “Learning masculinities and femininities: power/knowledge and legitimate peripheral participation” Women's Studies International Forum, Vol. 26 No. 6 pp: 541-552.

[28] Connell, R. W. \& Messerschmidt, J. W. (2005), "Hegemonic masculinity: Rethinking the concept" Gender and Society, Vol. 19 pp: 829-859.

[29] West, C. \& Zimmerman, D. (1987), “Doing gender” Gender and Society, Vol. 1 pp: 125-151.

[30] Burke, P. J. \& Stets, J. E. (2009), Identity Theory. New York, Oxford University Press.

[31] Koenig, A. (2018), "Comparing Prescriptive and Descriptive Gender Stereotypes About Children, Adults, and the Elderly" Frontiers in Psychology, Vol. 9 pp: 1086-1089. doi: 10.3389/fpsyg.2018.01086.

[32] Cohen, L., Manion, L., \& Morrison, K. (2017). Research methods in education. London: Routledge Taylor and Francis Group.

[33] Hernan A., Philpot B., Edmonds A., Reddy P. (2010). Healthy minds for country youth: Help-seeking for depression among rural adolescents. Australian Journal of Rural Health, 18, 118-124.

[34] Vogel D. L., Wade N. G., Wester S. R., Larson L., Hackler A. H. (2007). Seeking help from a mental health professional: The influence of one's social network. Journal of Clinical Psychology, 63, 233-245.

[35] Biddle L., Gunnell D., Sharp D., Donovan J. L. (2004). Factors influencing help seeking in mentally distressed young adults: A cross-sectional survey. British Journal of General Practice, 54, 248-253.

[36] Clement S., Schauman O., Graham T., Maggioni F., Evans-Lacko S., Bezborodovs N., .Thornicroft G. (2015). What is the impact of mental-health related stigma on 
help-seeking? A systematic review of quantitative and qualitative studies. Psychological Medicine, 45, 11-27.

[37] Hoy S. (2012). Beyond men behaving badly: A meta-ethnography of men's perspectives on psychological distress and help seeking. International Journal of Men's Health, 11(3), 202-226.

[38] Doublin, K. (2015). Personality traits of accounting professionals in different practice areas. Honours Dissertation. Appalachian State University, North Carolina, USA.

[39] Levy, J.J., Richardson, J.D., Lounsbury, J.W., Stewart, D., Gibson, L.W., \& Drost, A.W. (2011). Personality traits and career satisfaction of accounting professionals. Individual Differences Research, 1(1), 238-249.

[40] Hadebe, L. (2017). Zulu masculinity: Culture, faith and the constitution. In D. Gennrich (Ed.), Men and masculinities in South Africa: Understanding masculinity in South Africa: Essays and Perspectives (Vol. 2, pp. 5-28).

[41] Zimmerman, B.J., \& Schunk, D.E. (Eds.). (1989). Self-regulated learning and academic achievement: Theory, research, and practice. New York: Springer-Verlag.

[42] Thébaud, S. (2010). Masculinity, bargaining, and breadwinning: Understanding men's housework in the cultural context of paid work. Gender \& Society, 24(3), 330-354.

[43] DiMenichi, B.C., \& Tricomi, E. (2015). The power of competition: Effects of social motivation on attention, sustained physical effort, and learning. Frontiers in Psychology, 6(1), 1-13.

[44] Cretsinger, M. (2003). Academic competitiveness amongst graduate students. (Masters Dissertation). University of Wisconsin-Stout, Wisconsin, USA.

[45] Mapuya, M. (2018). First year student teachers' perceptions of their constructivist classroom learning environments in accounting 1 and implications for teacher educators. Unpublished masters thesis. Central University of Technology.

[46] Marrs, H., Sigler, E.A., \& Brammer, R.D. (2012). Gender, masculinity, femininity and help seeking in college. Masculinities and Social Change Magazine, 1(3), 267-292. 